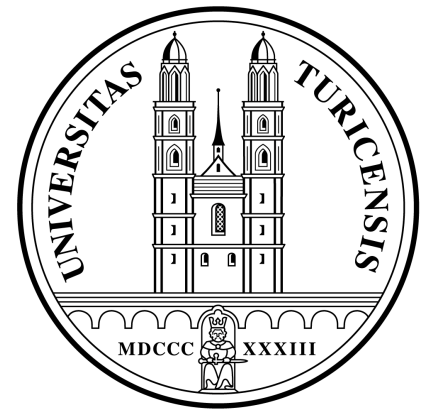

Institute for Empirical Research in Economics

University of Zurich

Working Paper Series

ISSN 1424-0459

published in: 'Organization Science', Vol. 11, No. 5, September - October 2000, pp. 538-550

Working Paper No. 27

Motivation, Knowledge Transfer, and

Organizational Form

Margit Osterloh and Bruno S. Frey

November 1999 


\title{
Motivation, Knowledge Transfer, and Organizational
}

\section{Forms}

\author{
Margit Osterloh \\ Institute for Research in Business Administration, University of Zurich, \\ Plattenstrasse 14, CH-8032 Zurich / Switzerland \\ Tel: $++41-1-6342841 / 40$ \\ Fax:++41-1-634 4942 \\ email: osterloh@ifbf.unizh.ch \\ and \\ Bruno S. Frey \\ Institute for Empirical Economic Research, University of Zurich, \\ Blümlisalpstrasse 10, CH-8006 Zurich / Switzerland \\ Tel: $++41-1-6343731 / 30$ \\ Fax:++41-1-634 4907 \\ email: bsfrey@iew.unizh.ch
}

\section{Acknowledgments}

We thank Iris Bohnet, Gary S. Becker, Jetta Frost, Raymond E. Miles, Felix Oberholzer-Gee, Oliver E. Williamson, Helmut Willke, Linda Zerilli, and three unknown referees for the helpful comments during the preparation of this article.

Key Words:

Motivation, Knowledge Transfer, Tacit Knowledge, Crowding Effects, Firm Theory, Resource-based View

JEL-Codes:

A12, J33, L22, M12 


\begin{abstract}
Employees are motivated intrinsically as well as extrinsically. Intrinsic motivation is crucial when tacit knowledge in and between teams must be transferred. Organizational forms enable different kinds of motivation and have different capacities to generate and transfer tacit knowledge. Since knowledge generation and transfer are essential for a firm's sustainable competitive advantage, we ask specifically what kinds of motivation are needed to generate and transfer tacit knowledge, as opposed to explicit knowledge.
\end{abstract}




\section{Introduction}

Knowledge generation and transfer is an essential source of firms' sustainable competitive advantage. The question is, which organizational form is most conducive to knowledge generation and transfer? The most prominent suggestion for organizing firms is to introduce market elements and prices through such methods as profit centers, spin-offs, or holdings. We intend to show that such organizational forms are suitable only under special circumstances defined by specific aspects of knowledge and motivation. In line with the knowledge-based view of the firm, we distinguish explicit from tacit knowledge. We ask what kinds of motivation are needed to generate and transfer tacit, as opposed to explicit, knowledge. To explore this question, we resort to a well-established and widely empirically supported social psychological theory of the interaction between intrinsic and extrinsic motivation. This theory, introduced into economics as crowding theory , is applied here to organization theory.

Intrinsic motivation is not simply additive to the motivation induced by prices (extrinsic incentives). Rather, under some conditions the use of the price system undermines intrinsic motivation (crowding-out effect), making motivation endogenous to organizational forms. We argue that knowledge transfer is intimately connected to motivation and that sustainable competitive advantage requires a corresponding motivation management. We will demonstrate which organizational forms are suitable for generating and transferring tacit as well as explicit knowledge. In addition, we will show the type of motivation, whether intrinsic or extrinsic, these organizational forms should engender for effective knowledge transfer and sustainable competitive advantage. 


\section{Knowledge as a Source of Competitive Advantage}

Increasingly, firms are being restructured by introducing market elements such as profit centers, divisional units, or holdings. The idea is to exploit the advantages of the price mechanism by making the exchanges between the actors or departments more explicit and by rewarding employees according to their contribution to the firm's profit. This strategy corresponds to a view of firms as the governance structure "of last resort, to be employed when all else fails" (Williamson 1975; 1985; 1991, p. 279).

This view, espoused by many economists, has recently been challenged:

Today, we know that ... to run a firm as if it were a set of markets, is ill-founded. Firms replace markets when non-market means of coordination and commitment are superior. (Rumelt, Schendel, and Teece 1991, p. 19)

What "non-market" organization means is left unexplored. The resourcebased theory of the firm (e.g., Barney 1991; Prahalad and Hamel 1990; Winter 1995), which is the leading alternative approach to the economic view, is also vague with respect to organizational forms. Adherents of the resource-based view generally agree that the most strategically important resource is knowledge (e.g. Conner and Prahalad 1996; Grant 1996a, b; Kogut and Zander 1996; Langlois and Foss 1999; Liebeskind 1996; Nahapiet and Ghoshal 1998; Pettigrew and Whipp 1993, pp. $212-$ 238; Spender 1996). Knowledge differs from information in that 
[l]nformation is a flow of messages, while knowledge is created by that very flow of information, anchored in the beliefs and commitment of its holder. ... (K)nowledge is essentially related to human action. (Nonaka and Takeuchi 1995, pp. 58-59)

\begin{abstract}
A further important distinction has been drawn between tacit and explicit knowledge (Polanyi 1966). Explicit knowledge can be coded in writing or symbols. ${ }^{1}$ But only a small part of our knowledge is explicit; "we can know more than we can tell" (Polanyi 1966, p. 4). This distinction between the two types of knowledge is important because of the transferability and appropriability of explicit knowledge, as opposed to tacit knowledge (Grant $1996 \mathrm{a}, \mathrm{b}){ }^{2}$ Tacit knowledge is acquired by and stored within individuals and cannot be transferred or traded as a separate entity. Explicit knowledge has the character of a public good (with the exception of patents or copyrights).
\end{abstract}

Two important consequences follow. First, tacit knowledge is a crucial source of sustainable competitive advantage because it is difficult for competitors to imitate it (e.g.,Teece 1998). Second, the contribution of a particular employee's tacit knowledge to a team output cannot be measured and paid accordingly. This has important motivational ramifications. 


\section{Extrinsic and Intrinsic Motivation}

Following economists' advice to "run a firm as if it were a set of markets" means rewarding employees according to their marginal productivity and relying on extrinsic rather than intrinsic motivation. ${ }^{3}$

\subsection{Conceptual Issues}

Employees are extrinsically motivated if they are able to satisfy their needs indirectly, especially through monetary compensation. Money is a "goal which provides satisfaction independent of the actual activity itself" (Calder and Staw 1975, p. 599). ${ }^{4}$ Extrinsically motivated coordination in firms is achieved by linking employees' monetary motives to the goals of the firm. The ideal incentive system is strict pay-for-performance.

Although many economists admit the existence of intrinsic motivation, ${ }^{5}$ they leave it aside because it is difficult to analyze and control (e.g., Williamson 1985, p. 64). Even if the assumption of opportunism is an "extreme caricature" (Milgrom and Roberts 1992, p. 42), opportunism as a "worst-case scenario" is a prudent consideration when designing institutional structures (Williamson 1996). ${ }^{6}$ Transactions cost theory goes a step farther by assuming that individuals are opportunistic and seek self-interest with guile. Opportunism is a strong form of extrinsic motivation when individuals are not constrained by any rules. In the transactions cost view, the task is to establish institutional settings that mitigate the hazards and costs of opportunistic behavior (Williamson 1985, 1996).?

Motivation is intrinsic if an activity is undertaken for one's immediate need satisfaction. Intrinsic motivation "is valued for its own sake and appears to be self 
sustained" (Calder and Staw 1975, p. 599; see also Deci 1975, p. 105). Intrinsic motivation can be directed to the activity's flow (Csikszentmihalyi 1975), to a selfdefined goal such as climbing a mountain (Loewenstein 1999), or to the obligations of personal and social identities (March 1994, p. 66; March 1999, p. 377). The ideal incentive system is in the work content itself, which must be satisfactory and fulfilling for the employees.

The behavioral view of organization emphasizes intrinsic motivation. This approach has a long tradition in motivation-based organization theory (Argyris 1964; Likert 1961; McGregor 1960). Intrinsic motivation is also drawn upon by critics of transaction cost theory (e.g., Donaldson 1995; Ghoshal and Moran 1996; Pfeffer 1997), as does the literature on psychological contracts (e.g. Morrison and Robinson 1997; Rousseau 1995). They emphasize intrinsic motivation in the form of identification with the firm's strategic goals, shared purposes, and the fulfillment of norms for its own sake.

Proponents of the behavioral view tend to look only at the positive aspects of intrinsic motivation. They consider intrinsic motivation to be an undisputed organizational advantage because it lowers transaction cost and raises trust and social capital (e.g., Ghoshal and Moran 1996; Kohn 1993; Nahapiet and Ghoshal 1998). However, intrinsically motivated employees do not always work to the benefit of their employers. Thus, intrinsic motivation has both disadvantages and advantages.

\subsection{Disadvantages of Intrinsic Motivation}

Motivation is not a goal in itself but should serve to support a firm's goals. Enterprises are not interested in producing some kind of intrinsic motivation with their 
employees, say, the joy of stamp collecting. Rather, employees must be motivated to perform in a coordinated and goal oriented way. For this purpose, managers must compare the benefits and costs related to motivating employees intrinsically and extrinsically. Two specific problems arise in connection with relying on intrinsic motivation in an organization. First, changing intrinsic motivation is more difficult, and the outcome more uncertain, than relying on extrinsic motivation, or carrots and sticks. For this reason, economists as well as managers traditionally prefer a reward and command policy (Argyris 1998). Second, intrinsic motivation can have an undesirable content. As history shows, some of the most terrible crimes have been motivated intrinsically, at least in part. Envy, vengeance, and the desire to dominate are not less intrinsically motivated than altruism, conscientiousness, and love. All of these motives contribute to immediate satisfaction rather than to achieving externally set goals.

To discipline the effects of undesirable intrinsic motivation, external interventions via carrots and sticks are needed. Management makes unwanted outcomes of intrinsic motivation on coworkers, superiors, and customers costly and therefore less attractive. ${ }^{8}$ In a careful analysis, Hirschman (1977) shows that uncontrolled passions are generally checked by economic interests. Montesquieu (1749) took as self-evident in his doctrine of "doux commerce"" that "commerce improves and mitigates our behavior as we can see every day." "Commerce," or external reward, makes extrinsic motivated behavior easier to calculate than intrinsic motivation. 


\subsection{Advantages of Intrinsic Motivation}

Although intrinsic motivation has disadvantages, under specific conditions it is superior to extrinsic motivation in circumstances relevant for organizations. First, intrinsic motivation is needed for tasks that require creativity. In contrast, extrinsically motivated persons tend to produce stereotyped repetition of what already works (e.g. Amabile 1996, 1998; Schwartz 1990). In addition, experimental research shows that the speed of learning and conceptual understanding are reduced when people are monitored. With extrinsically motivated employees, therefore, the pressure of sanctions leads to lower learning levels and the work performed is more superficial than with intrinsically motivated employees (Deci and Flaste 1995, p. 47).

Second, intrinsic motivation also helps overcome the so-called multiple task problem (Gibbons 1998; Holmstrom and Milgrom 1991; Prendergast 1999), where contracts cannot completely specify all relevant aspects of employee behavior and its desired outcome. Moreover, the goals to be set are often not clear to the principals. Financial goals cannot always be broken down into operational goals for employees. ${ }^{9}$ Accordingly, contracts offering incentives to reach given goals can give rise to dysfunctional behavioral responses. Agents focus only on the rewarded aspects of the job and disregard the unrewarded ones. Nor do they have sufficient incentives to reflect on the adequacy of the goals they should achieve for the overall success of the firm. Multiple task problems are the subject of incomplete contracts, which are characteristic of employment contracts (e.g. Conner and Prahalad 1996; Simon 1951; Williamson 1975). Empirical evidence suggests that the outcome of incomplete contracts will not normally be evaluated by variable pay-for-performance. Rather, firms rely considerably on intrinsic motivation (Austin 1996). 
Finally, and most important, intrinsic motivation enables the generation and transfer of tacit knowledge under conditions in which extrinsic motivation fails. In these cases, the multiple task problem is combined with the problem of "free riding" in teams.

\section{Motivation Crowding Effects}

If the two types of motivation were independent and additive, intrinsic and extrinsic motivation could be managed by firms according to their relative advantages and disadvantages. The separation of intrinsic and extrinsic motivation would also correspond to a useful division of labor between psychology (focussing on intrinsic motivation) and economics (focussing on extrinsic incentives). However, a large number of careful experiments in psychology (e.g. deCharms 1968; Deci 1971, 1975; Deci and Flaste 1995; Deci and Ryan 1980, 1985; Staw 1975), as well as field research in economics (Barkema 1995; Frey 1997a), strongly suggest that under specific conditions there is a trade-off between the two types of motivation. The most important condition for this trade-off is the existence of intrinsic motivation in the first place. In psychology, the trade-off has been called the "hidden costs of reward" (Lepper and Greene 1978) or "the corruption effect of extrinsic motivation" (Deci 1975). ${ }^{10}$ In economics, Frey (1997a) introduced the corruption effect as "'crowdingout."'

Many parents are intuitively aware of the corruption effect. Children who are initially enthusiastic about a task lose part of their interest when they are promised a reward for fulfilling the task. An example is the attempt to motivate children with rewards for doing their homework. In the short run, this measure is often successful. In the longer run, however, the effect is that the children will do their homework only if 
they receive a monetary reward. The crowding out effect has set in. Moreover a spillover effect often occurs. The children don't do any housework except they are paid.

\subsection{Analysis of the Crowding Effect}

Theoretical foundations for the crowding effect are based on cognitive evaluation theory (Deci 1975) and on psychological contract theory (Rousseau 1995; Schein 1965). These two psychological approaches have been developed largely independent of each other. Taken together, they specify the conditions under which intrinsic motivation is decreased or increased. These theories concentrate on preferences, i.e., attitudes referring to individuals' structure of values. In contrast, traditional economists take values as constant and focus on constraints such as given prices, limited income, and time (e.g., Becker 1976; Frey 1999; Stigler and Becker 1977). Our crowding theory acknowledges that observed behavior depends on both preferences and constraints, relative prices in particular. Thus, we combine psychological and economic approaches.

Cognitive evaluation theory. According to cognitive evaluation theory advanced by Deci (1975), intrinsic motivation depends on the perceived locus of control. If the impetus for an action is attributed to an external influence, the perceived cognitive self-determination is undermined. Individuals who feel forced by outside intervention to behave in a specific way would be "overjustified" if they maintained their intrinsic motivation. The locus of control shifts from inside to outside the person (Rotter 1966). The actor attributes responsibility to the person undertaking the outside intervention. 
A shift in the locus of control does not always take place. Each external intervention, e.g., a reward, has two aspects: a controlling and an informing aspect. The controlling aspect strengthens perceived external control and the feeling of being stressed from the outside. The informing aspect influences one's perceived competence and strengthens the feeling of internal control. Depending on which aspect is prominent, intrinsic motivation is reduced or raised. ${ }^{11}$

A positive effect on intrinsic motivation of an external intervention or institution is called crowding-in. A negative effect is called crowding-out. If achieving a task is at the same time extrinsically and intrinsically motivated, the more devalued the attribution of a self-determined action is, the more strongly the individuals believe themselves to be subject to outside control. What matters is that when one goal is taken to be instrumental for reaching another goal, the first goal loses its value (Kruglanski 1975).

Psychological Contracts. Social psychologists (Rousseau and McLean Parks 1993, Schein 1965), as well as some unorthodox economists (e.g. Akerlof 1982), suggest that contracts may involve strong emotional ties and loyalties. These socio-emotional relations establish an implicit contract that goes beyond transactional exchanges but include a reciprocal appreciation of intrinsic motivation. If such a contract is breached, the reciprocal good faith is put into question. In this case, as empirical evidence shows (Robinson, Kraatz and Rousseau 1994), the parties to the contract perceive that the employment arrangement is transformed into an extrinsically motivated (transactional) contract. For example, when guests express their appreciation of a host's efforts with a symbolic gift (such as a bunch of flowers), the host's intrinsic motivation 
tends to be raised. However, when guests try to present money as a gift, the host's intrinsic motivation is decreased.

An important part of psychological contracts involves perceptions of fairness. Experiments and field studies show that fairness increases the willingness to perform and decreases shirking (Fehr, Gächter and Kirchsteiger 1997; Kim and Mauborgne 1991, 1998; Tyler 1990).

The reciprocal appreciation of motives also explains why commands normally crowd-out intrinsic motivation more than the use of prices. Commands do not take into account the motives of the recipients, while the price system leaves the choice open as to whether one cares to receive the reward or not.

Crowding theory. As pointed out, observed behavior depends on preferences or intrinsic motivation (emphasized by psychologists) and on constraints or relative prices (emphasized by economists). Crowding theory considers both (Frey 1997a). External interventions, therefore, may have a positive or negative effect on work effort, depending on whether the effect on constraints or on preferences dominates.

This relationship is illustrated in Figure 1, depicting a supply curve (S) for labor effort. As some amount of intrinsic work motivation is assumed to exist, the amount (OA) of labor effort is supplied even if no compensation is paid. If a reward $(R)$ is paid to perform the work the price effect raises work effort to B along the supply curve S. If intrinsic work motivation is undermined, the supply curve is shifted backwards to S'. Work effort is thus supplied at point $\mathrm{C}$. The figure is drawn in such a way that the motivation effect dominates the price effect: the rise in the reward reduces work effort from $B$ to $C$. When the motivation effect is smaller, i.e., when the 
supply curve shifts less backwards, a rise in the reward may well increase the amount of work effort.

(Figure 1)

Figure 1 underlines why the argument that it is prudent to consider a worstcase scenario (Williamson 1996; Milgrom and Roberts 1992, p. 42) is incomplete. Williamson's (e.g. 1975, p. 48; 1996) basic assumption that the price system should be used to protect against the danger of opportunistic behavior promotes the conditions from which his argument starts. Figure 1 also enables a better understanding of Ghoshal and Moran's (1996, pp. 21-27) critique of the behavioral assumptions of transactions cost theory. When the use of the price system in the firm crowds out intrinsic motivation, the proclivity toward opportunistic behavior increases. In the extreme case, there is no intrinsic motivation left.

The crowding theory deals with the effects of changes in preferences and constraints on behavior. Since they may work in opposite directions (as in Figure 1), an empirical analysis is needed.

\subsection{Empirical evidence}

It is impossible to summarize here the results of the large number of laboratory experiments on the crowding effect. Fortunately, no less than five formal meta-analytical studies of the crowding theory have already been completed.

Rummel and Feinberg (1988) used 45 experimental studies covering the period 1971 to 1985; Wiersma (1992), 20 studies covering 1971 to 1990; and Tang and Hall (1995), 50 studies from 1972 to 1992 . These meta-analyses essentially support the 
findings that intrinsic motivation is undermined if the externally applied rewards are perceived by the recipients to be controlling.

This view was challenged by Cameron and Pierce (1994) and Eisenberger and Cameron (1996), who concluded that the undermining effect is largely "a myth" on the basis of their own meta-analysis of studies published in the period 1971 to 1991 (the two studies are based on a virtually identical set of studies). These studies attracted a great deal of attention, and many scholars seem to have concluded that no such thing as a crowding-out effect exists.

Deci, Koestner and Ryan (forthcoming) conducted an extensive study to show that these conclusions are unwarranted and that the crowding-out effect is a robust phenomenon under specified conditions. Deci, Koestner and Ryan (forthcoming) identified a number of significant shortcomings and misinterpretations in Cameron and Pierce's analysis. Shortcomings include the omission of nearly 20 percent of the relevant studies as outliers; the use of mistaken control groups; and the misclassification of some of the studies. In addition, Cameron and Pierce included dull and boring tasks for which a crowding-out effect could not occur, since the participants had no intrinsic motivation to begin with.

To correct these failures, Deci, Koestner and Ryan (forthcoming) conducted an extensive meta-analysis including all the studies considered by Cameron, Pierce, and Eisenberger, as well as several studies that appeared after theirs. The 68 experiments reported in 59 articles span the period 1971 to 1997 and refer to 97 experimental effects. It turns out that tangible rewards undermine intrinsic motivation for interesting tasks (i.e., tasks for which the experimental subjects show an intrinsic interest) in a highly significant and very reliable way and that the effect is moderately 
large. This undermining is particularly true for monetary compensations that were perceived by the experimental subjects to be controlling and therefore tended to crowd out intrinsic motivation. The crowding-out effect was stronger with monetary than with symbolic rewards. The crowding-out effect was also larger with expected than with unexpected rewards. When the problems at issue were complicated, the negative relationship between reward and performance was stronger than when the problems were simple (see Deci and Ryan 1985; Heckhausen 1991, ch. 15). In all cases, the behavior was initially perceived to be interesting and therefore intrinsically rewarding (Calder and Staw 1975).

The relevance of the crowding-out effect is also supported by numerous field studies. In an econometric study of 116 managers in medium-sized Dutch firms, Barkema (1995) found that the number of hours worked in the company decreased under intense supervision by the superiors. These econometric results are consistent with circumstantial evidence proposed by McGregor's (1960) theory X and theory Y. On this basis, Argyris (1964) suggests that strong control leads to an ever expanding need to increase control.

Another real-life case for the crowding-out effect is provided by blood donations, as argued by Titmuss (1970). Paying donors for giving blood undermines the intrinsic motivation to do so. Though it is difficult to isolate the many different influences on blood supply, in countries where most of the blood is supplied gratis, paying for blood is likely to reduce total supply (Upton 1973).

The crowding-out effect has also been shown to exist in econometric

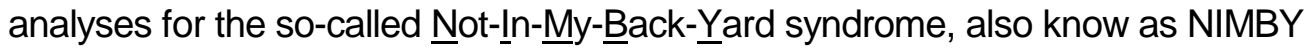
syndrome (Frey and Oberholzer-Gee 1997; Frey, Oberholzer-Gee and Eichenberger 
1996). In a carefully designed survey for a community located in central Switzerland, more than half the respondents ( 50.8 per cent) agreed to have a nuclear waste repository built in their commune. When compensation (in monetary terms) was offered, the level of acceptance dropped to 24.6 per cent.

Baumol and Oates (1979), Hahn (1989) and Kelman (1981) observed that under certain conditions the introduction of environmental charges has little effect. When a punishment for environmental pollution is perceived to be strongly controlling, people are demotivated to protect the environment for intrinsic reasons.

The crowding-in effect has been investigated less, but is supported by at least one econometric study. A cross-section analysis of the 26 cantons in Switzerland with varying degrees of direct democratic institutions shows that in cantons with better developed institutions of direct democracy, citizens exhibit a higher intrinsic motivation to pay taxes than in those cantons with less participation rights. Cantons with better developed democratic institutions are more informed and feel more fairly treated. Consequently they are less inclined to evade taxes (Frey 1997b).

As pointed out, no crowding-out can take place if there is no intrinsic motivation in the first place. This condition obtains for simple jobs. In such cases, empirical evidence shows that the price effect increases performance. Lazear (1996) provides an empirical example. He finds that in a large auto glass company, productivity increases of between 20 percent to 36 percent of output were reached when the firm switched from paying hourly wages to piece rates. 


\subsection{Organizational Consequences of Motivation Crowding Effects}

Although general crowding effects have not been fully explored, we can still surmise the consequences of specific organizational designs on motivation. We focus on three aspects of crowding effects that should be taken into consideration when integrating market elements (such as profit centers or variable pay for performance) into the firm.

Participation is an alternative to markets as a coordination mechanism. Participation signifies an agreement on common goals. Participation raises the perceived self-determination of employees and therewith strengthens intrinsic motivation. As experiments show, this the strengthening of self-determination and intrinsic motivation takes place only when agreements about the goals serve primarily as self-control and self-obligation. In contrast, perceived external control inhibits creativity in the pursuit of goals (see Schwartz 1990). These experimental findings support the concept of management by objectives as a process of joint goal setting between a principal and an agent (e.g. Raia 1974). The recent emphasis on "empowerment" (see e.g. Wellins, Byham and Wilson 1991) also reflects this relationship.

Personal relationship in lieu of the anonymous market is a precondition for establishing psychological contracts based on emotional loyalties, often called team spirit. Team-based structures enable such personal relationship. As experimental research shows, personal relationship strongly raises the intrinsic motivation to cooperate (e.g. Dawes, van de Kragt and Orbell 1988; Frey and Bohnet 1995). These findings confirm that Likert's (1961) linking-pin-organization as a network of interlocking teams indeed raises intrinsic motivation based on psychological 
contracts. In contrast, neither perfect markets nor the price system rely on psychological contracts. An example is the anonymous relationship between buyers and sellers on financial markets. Adam Smith (1776) was one of the first to recognize that the absence of personal relationship or social atomization is a prerequisite for perfect competition.

Contingency of reward on performance can crowd out intrinsic motivation. This holds provided the perceived controlling effect of reward is stronger than the perceived informing effect and the price effect is overruled. The crowding-out effect provides a possible interpretation for the overwhelming empirical evidence that there is generally no valid connection between pay and performance. Instead, the "literature on incentive plans is full of vivid descriptions of the counterproductive behaviors that piece-rate incentive plans produce" (Lawler III 1990, p. 58). The same holds for managerial compensation (for recent surveys see Barkema and GomezMejia 1998; Prendergast 1999), a fact admitted even by the proponents of principal agent theory (e.g. Güth 1995; Jensen and Murphy 1990), who favor time-based compensation and oppose strict forms of variable pay-for-performance in situations that need high intrinsic motivation.

\section{Combining Motivational and Knowledge Requirements}

Managing motivation, especially balancing intrinsic and extrinsic motivation, is an important and hard-to-imitate competitive advantage. This capability is crucial for all tasks in which the goals are difficult to formulate and where it is difficult to attribute task completion to particular employees. As pointed out, the generation and transfer of knowledge often constitutes such a task. At the same time the generation and transfer of knowledge is the most crucial resource of firms. Employees who are 
extrinsically motivated could resort to free riding. This situation cannot be alleviated by strengthening the carrot-and-stick policy when the conditions for crowding-out apply. In such conditions, external interventions undermine the needed intrinsic motivation of employees.

However, managing intrinsic motivation is difficult and often risky. Situations that require intrinsic motivation must be distinguished from those that do not. Markets rely systematically on price effects and therefore can crowd out the intrinsic motivation needed for specific forms of knowledge generation and transfer. We contrast organizational forms that integrate market elements into firms with those not using market elements.

The following cases illustrate our basic point that when the transfer of tacit knowledge is at stake, introducing market mechanisms is bad advice (Chesbrough and Teece 1996). With the launch of its first personal computer in 1981, IBM chose to outsource all the major components. The microprocessor was bought from Intel, while the operating system was licensed from Microsoft. Moreover, the distribution channels were outsourced to a large number of retailers such as ComputerLand, Sears, BusinessLand, and MicroAge. The strong extrinsic incentives produced by the market enabled IBM to get its first PC to market in only 15 months and to launch an attack against Apple, the market pioneer. However, with the passage of time, IBM had to learn a lesson. Because outsourcing necessitates making knowledge explicit to allow production and service level agreements, the competitors in the markets for PCs had an open door to imitate. They could buy the same operating system from Microsoft, the same software from Lotus, WordPerfect, and Microsoft and use the same distribution channels. As a result, IBM lost much of its competitive advantage as well as its ability to direct the evolution of the PC architecture. 
However, the right balance between insourcing and outsourcing is crucial because no company is able to develop internally all the technology necessary for a successful future product. Chesbrough and Teece (1996, pp. 70-73) discuss Motorola, a leader in wireless communication technology, as a firm that has chosen the right balance. To retain its competitive advantage over the long run, battery technology is critical for Motorola. It therefore develops the critical parts of its value chain (fuel cells and solid-state energy sources) internally and buys the less critical battery technologies, such as nickel cadmium, on the market.

Table 1 presents a typology of organizational forms. It discusses which organizational forms can best enable the transfer of explicit or tacit knowledge with respect to the required extrinsic or intrinsic motivation. The four types of organization occur only rarely in pure form. For the sake of clarity, we will not consider hybrid forms of organization like strategic alliances and interfirm networks (see Koza and Lewin 1997; Miles et al. 1997; Sydow and Windeler 1998).

\section{(Table 1)}

Cell 1 describes the situation commonly considered by economists when they suggest running a firm "as if it were a set of markets." Prominent examples of this advice are profit centers, spin-offs, or holdings. An effort is made to replace commands by contracts and transfer prices. This advice is well taken if the necessary knowledge to be transferred between the decentralized units is either encapsulated in a marketable product or is otherwise explicit. Only explicit tasks are communicable by means of contracts. In situations of a marketable product or a contract, monetary rewards and extrinsic motivation fulfill their task. ${ }^{12}$ In the case of profit centers, transfer prices referring to comparable market prices serve to calculate the 
contribution of each unit to the corporate outcome. Transfer prices help to remunerate leaders of profit centers according to their performance. ${ }^{13}$

But as the example of IBM shows, a problem arises when the resources become imitable ${ }^{14}$ The very idea of extrinsically motivated competition between decentralized units hinders the flow of tacit knowledge to where it is needed. Therefore the critical parts of the value chain should not be outsourced or separated into different profit centers.

Cell 2 considers the case of "knowledge-based production teams." The exchange of tacit knowledge is concentrated within an organizational unit. In addition, knowledge remains tacit and cannot be translated into action subject to commands. ${ }^{15}$ Examples are the construction of complex facilities or the development of an outstanding product design like Benetton's fashion design (Richardson 1996; Grant 1996a). The tacit knowledge is embodied in the product itself or in the firm-specific routinized processes leading to the product. Because of the tacitness of this knowledge, it can neither be made explicit via reverse engineering nor can it be encapsulated in an expert-system software. In the case of Benetton, fashion design moreover has to be integrated with garment knowledge, Benetton's own market knowledge, and its manufacturing expertise. As in the cases of IBM and Motorola mentioned above, such activities are the basis for a long-run competitive advantage in the form of core competencies that are difficult to imitate. To keep this advantage, these activities have to remain inside a work team and should not be dissected into profit centers or outsourced.

There are reasons for containing tacit knowledge at both the team and the individual level. At the team level, competition between firms as well as between profit 
centers hinders the transfer of tacit knowledge. The members of a unit have no incentive to give up their individual competitive knowledge advantage as long as they are compensated according to the unit's profitability. Because of the uncodifiable nature of tacit knowledge as part of the multiple task problem, the transfer of tacit knowledge cannot be assured by a complete contract (e.g. Madhok 1997).

At the individual level, employees cannot be identified and sanctioned if they hold back their tacit knowledge. Peer pressure, often presumed to be a solution to the free riding problem (Kandel and Lazear 1992), does not work here at the individual level. Agents cannot monitor one another or mete out punishments to those who do not process tacit knowledge. An example (particularly relevant to us) is the joint production of this paper. Each author is unable to determine the share of one's contribution to the joint output.

The well-known solution to the team production problem developed by Alchian and Demsetz (1972) does not apply to tacit knowledge. Alchian and Demsetz deal with physical activities demonstrated by jointly lifting cargo into a truck. In this case, each team member would realize if another one is shirking. The team member acting as a residual claimant is able to assess the contribution of the other team members and can prevent shirking. Such assessment becomes more difficult if the product of team work does not consist in physical activities but in processing explicit knowledge, which is harder to measure. Preventing shirking is impossible when tacit knowledge has to merge within the team. The joint output can be evaluated solely on the market. Tacit knowledge can be efficiently marketed only if it is encapsulated in goods or services. ${ }^{16}$ It follows that in the absence of intrinsic motivation, free riding will take place. 
So far, we have argued to what extent intrinsic motivation is required in knowledge-based production teams. But how can this required motivation be achieved? First, we have shown that participation and personal relationship foster employees' intrinsic motivation because their perceived self-determination is raised and psychological contracts are established: the so-called "team spirit" is enabled. Second, crowding-out effects are to be avoided by refraining from individual variable pay-for-performance and the resulting competition. Empirical evidence shows that in teams, helping efforts are reduced by individual incentives (Drago and Garvey 1998). For this reason, time-pay according to the qualifications of the team members (Gibbons 1998) is often the practice. In team-based compensation, a crowding-in effect is produced if pay is accompanied by nonfinancial social recognition strengthening perceived competence. ${ }^{17}$ Third, effort can be put into selecting intrinsically motivated persons for the tasks at hand. In any case, an intrinsic motivation to generate and transfer tacit knowledge cannot be compelled but can only be enabled under suitable conditions. By its nature, intrinsic motivation is always voluntary. $^{18}$

The generation and transfer of explicit knowledge is not associated only with extrinsic motivation, nor does the transfer of tacit knowledge always require intrinsic motivation. Cell 3 deals with those cases where parts of tacit knowledge are made explicit. As Nonaka and Takeuchi (1995, pp. 64-73) show, the conversion of tacit into explicit knowledge at the individual level is an important part of the process of creating firm-specific tacit knowledge. During this process, individual tacit knowledge is amplified and crystallized in the form of routines. According to the resource-based view of the firm, organizational routines, embodied in the individual's as well as in the 
firm's tacit knowledge, are the most sustainable source of hard-to-imitate competitive advantages (Fransman 1998; Hodgson 1998; Nelson 1991).

Nonaka and Takeuchi (1995, p. 73) characterize the process of organizational knowledge creation as "knowledge spiral," in which tacit and explicit knowledge interact during four modes of knowledge conversion. In the socialization mode, tacit knowledge is shared between individuals mainly as learning by doing. In the externalization mode, parts of tacit knowledge are translated into explicit knowledge. Externalization is supported by metaphors, analogies, narratives, or visuals. In the combination mode, different explicit knowledge is bundled together, mainly by the exchange of documents, computerized communication, or formal education. Thus, the body of explicit knowledge becomes enriched and systemized.

In the internalization mode, the new body of explicit knowledge is conversed into rules of action and practice, i.e., the "firm's memory" in the form of routines. Routines serve to enable the firm to deal with bounded rationality while at the same time acting as a repository of firm-specific knowledge (Winter 1995). To a high degree, routines are applied habitually and therefore become integrated into the body of tacit knowledge stored within individuals. At the same time, the habitually stored and practiced routines become integrated into the shared organizational tacit knowledge. The "knowledge spiral" turns around to a higher and richer level of shared knowledge.

Thus, both socialization and externalization are required to create an ever growing body of organizational routines. Externalization is the dominant mode of knowledge conversion in Cell 3, while socialization is prevalent in the activities of Cell 2. Externalization as part of the process of creating firm-specific routines takes place 
in "knowledge producing teams." Examples are quality circles or task forces. Both are widely used to enhance total quality and continuous improvement in many industries, e.g., in car manufacturing (e.g., Berggren 1994). Participants contribute their mostly tacit knowledge about the production process by using e.g. narratives. The aim is to implement improved routines, which become part of the firm's repository of knowledge.

As in Cell 2, the knowledge transfer itself cannot be observed and measured. However, its outcome can be both observed and measured. This outcome can not be attributed to an individual working in a team. Hence, the conversion from tacit to explicit knowledge requires intrinsically motivated group members committing to the group (von Krogh 1998; Nonaka and Konno 1998). For this reason, in most cases these teams are formed voluntarily and their tasks are defined by themselves to support self-determination.

Cell 4 concerns independent knowledge workers in a firm. They are independent in the sense that they are not working in a team with cospecialized workers with whom they share tacit knowledge. ${ }^{19}$ Examples are lawyers or experts in computing or finance. These workers rely strongly on their specific tacit knowledge. The application of tacit knowledge itself cannot be measured, but its output can be compensated according to its value to the organization. In contrast to Cells 2 and 3 , this output can be attributed to the independent knowledge worker. In this case no intrinsic motivation is needed. But the performance of such independent knowledge workers does not contribute to a sustainable competitive advantage. Other firms can easily woo them away and profit from their tacit knowledge (Leonard and Sensiper 1998). 


\section{Conclusions}

Our analysis allows us to draw four conclusions. First, intrinsic motivation is important for firms. It has great advantages in areas where prices and markets play a minor role. The decision to rely on and enable intrinsic motivation depends strongly on the need to generate and transfer tacit knowledge. This knowledge is an important source for sustaining competitive advantage as demonstrated by the resource-based view of the firm. The transfer of tacit knowledge within and between teams cannot be directly observed and the output cannot be attributed to a particular employee. At best, managers can observe the result of knowledge generation and transfer in terms of output. Explicit knowledge, on the other hand, is tradable. Managers are more capable of observing how well workers with individual knowledge have performed in this respect, and can reward them accordingly.

Second, the crowding effects make both intrinsic and extrinsic motivation endogenous variables. Intrinsic motivation is not simply additive to extrinsic motivation induced by rewards. Crowding effects thus restrict the applicability of standard transactions cost and agency theory for organization design. The assumption of opportunism promotes the worst-case conditions against which these theories claim to protect.

Third, we suggest under which conditions the proposal to introduce market elements such as profit centers or holdings are beneficial. Markets systematically use extrinsic incentives for motivational purposes. No problem arises insofar as explicit knowledge is to be transferred or tacit knowledge is encapsulated in a product or service attributable to a residual claimant. In contrast, if tacit knowledge of several team members is crucial for a joint output (either in the form of a product or in the 
form of explicit knowledge), the use of market elements may lead to withholding knowledge that is needed to establish and preserve the competitive advantage of a firm. When the transfer of tacit knowledge within or between teams is crucial, (transfer) prices as well as commands are unsuitable for motivation. Instead, organizational forms that emphasize participation and personal relationship, such as linking pins or overlapping teams, are needed.

Fourth, firms may be interpreted in a new light. Firms are able to manage motivation better than the market. According to the relative advantages and disadvantages of intrinsic motivation, firm managers can choose an optimal combination and can obtain it by taking motivational crowding effects into account. 


\section{References}

Akerlof, G. A. (1982), "Labor Contracts as Partial Gift Exchange," Quarterly Journal of Economics, 84, pp. 488-500.

Akerlof, G. A. and J. L. Yellen (1986), Efficiency Wage Models and the Labor Market, Cambridge: Cambridge University Press.

Alchian, A. A. and H. Demsetz (1972), "Production, Information Costs and Economic Organization," American Economic Review, 62 (December), pp. 777-795.

Amabile, T. M. (1996), Creativity in Context: Update to the Social Psychology of Creativity, Boulder, CO: Westview Press.

Amabile, T. M. (1998), "How to Kill Creativity," Harvard Business Review, (September/October), pp. 77-87.

Argyris, C. (1964), Integrating the Individual and the Organization, New York: Wiley.

Argyris, C. (1998), "Empowerment: The Emperor's New Clothes," Harvard Business Review, (May/June), pp. 98-105.

Arrow, K. J. (1974), The Limits of Organization, New York: Norton.

Atkinson, John W. (1964), An Introduction to Motivation, Princeton, NJ: Van Nostrand.

Austin, R. D. (1996), Measuring and Managing Performance in Organizations, New York: Dorset House.

Baker, G. P., M. C. Jensen and K. J. Murphy (1988), "Compensation and Incentives: Practice Versus Theory," Journal of Finance, 43 (July), pp. 593616. 
Barkema, H. G. (1995), "Do Job Executives Work Harder When They are Monitored?," Kyklos, 48, pp. 19-42.

Barkema, H. G. and L. R. Gomez-Mejia (1998), "Managerial Compensation and Firm Performance. A General Research Framework," Academy of Management Journal, 41, pp. 135-145.

Barney, J. B. (1991), "Firm Resources and Sustained Competitive Advantage," Journal of Management, 17, pp. 99-120.

Baumol, W. J. and W. E. Oates (1979), Economics, Environmental Policy, and the Quality of Life, Englewood Cliffs, NJ: Prentice-Hall.

Becker, G. S. (1976), The Economic Approach to Human Behavior, Chicago: Chicago University Press.

Berggren, C. (1994), "Nummi vs. Uddevalla," Sloan Management Review, 36, Winter, pp. 37-49.

Brennan, G. and J. M. Buchanan (1985), The Reason of Rules: Constitutional Political Economy, Cambridge: Cambridge University Press.

Calder, B. J. and B. M. Staw (1975), "The Self-Perception of Intrinsic and Extrinsic Motivation," Journal of Personality and Social Psychology, 31, pp. 599-605.

Cameron, J. and W. D. Pierce (1994), "Reinforcement, Reward, and Intrinsic Motivation: A Meta-Analysis," Review of Educational Research, 64 (Fall), pp. 363-423.

Chesbrough, H. W. and D. J. Teece (1996), "When is Virtual Virtuous?:

Organizing for Innovation," Harvard Business Review, 74 (January/February), pp. 65-73.

Conner, K. R. and C. K. Prahalad (1996), "A Resource-Based Theory of the Firm: Knowledge Versus Opportunism," Organization Science, 7, 5, pp. 477-501. 
Csikszentmihalyi, M. (1975), Beyond Boredom and Anxiety, San Francisco: Jossey-Bass.

Dawes, R. M., A. J. C. van de Kragt and J. M. Orbell (1988), "Not Me or Thee But We: The Importance of Group Identity in Eliciting Cooperation in Dilemma Situations-Experimental Manipulations," Acta Psychologica, 68, pp. 83-97.

DeCharms, R. (1968), Personal Causation: The Internal Affective Determinants of Behavior, New York: Academic Press.

Deci, E. L. (1971), "Effects of Externally Mediated Rewards on Intrinsic Motivation," Journal of Personality and Social Psychology, 18, pp. 105115.

Deci, E. L. (1975), Intrinsic Motivation, New York: Plenum Press.

Deci, E. L. and R. Flaste (1995), Why We Do What We Do: The Dynamics of Personal Autonomy, New York: Putnam.

Deci, E. L. and R. M. Ryan (1980), "The Empirical Exploration of Intrinsic Motivational Processes," Advances in Experimental Social Psychology, 10, pp. 39-80.

Deci, E. L. and R. M. Ryan (1985), Intrinsic Motivation and Self-Determination in Human Behavior, New York: Plenum Press.

Deci, E. L.; R. Koestner and R. M. Ryan (forthcoming), "Extrinsic Rewards and Intrinsic Motivation: A Clear and Consistent Picture After All," Psychological Bulletin, forthcoming.

Demsetz, H. (1991), "The Theory of the Firm Revisited," in: O. E. Williamson and S. G. Winter (eds.), The Nature of the Firm, New York and Oxford: Oxford University Press. 
Donaldson, L. (1995), American Anti-Management Theories of Organization: A Critique of Paradigm Proliferation, Cambridge, UK: Cambridge University Press.

Drago, R. and G. T. Garvey (1998), "Incentives for Helping on the Job: Theory and Evidence," Journal of Labor Economics, 16, pp. 1-25.

Eccles, R. G. (1985), The Transfer Pricing Problem, Lexington, MA and Toronto: Lexington Books.

Eisenberger, R. and J. Cameron (1996), "Detrimental Effects of Reward: Reality Or Myth?" American Psychologist, 51, pp. 1153-1166.

Enzle, M. E. and S. Anderson (1993), "Surveillant Intentions and Intrinsic Motivation," Journal of Psychology and Social Psychology, 30, pp. 257-66.

Fehr, E., S. Gächter and G. Kirchsteiger (1997), "Reciprocity as a Contract Enforcement Device," Econometrica, 65, 4, pp. 833-860.

Feldman, L. P. (1996), "The Role of Salary and Incentives in the New Product Function," Journal of Product Innovation Management, 13, pp. 216-228.

Frank, R. H. (1992), "Melting Sociology and Economics: James Coleman's Foundations of Social Theory," Journal of Economic Literature, 30 (March), pp. $147-170$.

Fransman, M. (1998), "Information, Knowledge, Vision and Theories of the Firm," in: G. Dosi, D. J. Teece and J. Chytry (eds.), Technology, Organization, and Competitiveness, Oxford: Oxford University Press: 147-191.

Frey, B. S. (1997a), Not Just for the Money: An Economic Theory of Personal Motivation, Cheltenham, UK and Brookfield, USA: Edward Elgar.

Frey, B. S. (1997b), "A Constitution for Knaves Crowds Out Civic Virtues," Economic Journal, 107 (July), pp. 1043-1053.

Frey, B. S. (1999), Economics as a Science of Human Behaviour, $2^{\text {nd }}$ ed., Boston and Dordrecht: Kluwer. 
Frey, B. S. and I. Bohnet (1995), "Institutions Affect Fairness: Experimental Investigations," Journal of Institutional and Theoretical Economics, 151, 2, pp. 286-303.

Frey, B. S. and F. Oberholzer-Gee (1997), "The Cost of Price Incentives: An Empirical Analysis of Motivation Crowding-out," American Economic Review, 87 (September), pp. 746-755.

Frey, B. S., F. Oberholzer-Gee and R. Eichenberger (1996), "The Old Lady Visits Your Backyard: A Tale of Morals and Markets," Journal of Political Economy, 104, 6, pp. 193-209.

Gaitanides, M. (1997), "Integrierte Belieferung - Eine ressourcenorientierte Erklärung der Entstehung von Systemlieferanten in der Automobilzulieferindustrie," Zeitschrift für Betriebswirtschaft, 67, 7, pp. 737-757.

Ghoshal, S. and P. Moran (1996), "Bad for Practice: A Critique of the Transaction Cost Theory," Academy of Management Review, 21, 1, pp. 13-47.

Gibbons, R. (1998), "Incentives in Organizations," The Journal of Economic Perspectives, 12, 4, pp. 115-132.

Grant, R. M. (1996a), "Prospering in Dynamically-competitive Environments: Organizational Capability as Knowledge Integration," Organization Science, 7, 4, pp. 375-387.

Grant, R. M. (1996b), "Toward a Knowledge-based Theory of the Firm," Strategic Management Journal, 17 (Winter Special Issue), pp. 109-122.

Güth, W. (1995), "Shirking Versus Managerial Incentives of Chief Executive Officers (CEOs): A Note on a Possible Misunderstanding of the PrincipalAgency-Theory," Journal of Institutional and Theoretical Economics, (JITE) 151, 4, pp. 693-698. 
Hahn, R. W. (1989), "Economic Prescriptions for Environmental Problems: How the Patience Followed the Doctor's Orders," Journal of Economic Perspectives, 3, pp. 9-114.

Heckhausen, H. (1991), Motivation and Action, New York, Berlin and Heidelberg: Springer.

Hirschman, A. O. (1977), The Passions and the Interests: Political Arguments for Capitalism Before its Triumph, Princeton, NJ: Princeton University Press.

Hodgson, G. M. (1998), "Competence and Contract in the Theory of the Firm," Journal of Economic Behavior \& Organization, 35, pp. 179-201.

Holmstrom, B. and P. Milgrom (1991), "Multitask Principal-Agent Analyses: Incentive Contracts, Asset Ownership, and Job Design," Journal of Law, Economics \& Organization, 7 (Special Issue), pp. 24-52.

Jensen, M. C. and K. J. Murphy (1990), "Performance Pay and Top-Management Incentives," Journal of Political Economy, 98, pp. 225-264.

Kandel, E. and E. Lazear (1992), "Peer Pressure and Partnerships," Journal of Political Economy, 100, 4, pp. 801-817.

Kaplan, R. S. and D. P. Norton (1996), Translating Strategy into Action - The Balanced Scorecard, Boston, MA: Harvard Business School Press.

Kelman, S. (1981), What Price Incentives?: Economists and the Environment, Boston: Auburn House.

Kim, W. C. and R. Mauborgne (1991), "Implementing Global Strategies: The Role of Procedural justice," Strategic Management Journal, 12, pp. 125-143.

Kim, W. C. and R. Mauborgne (1998), "Procedural Justice, Strategic Decision Making, and the Knowledge Economy," Strategic Management Journal, 19, pp. 323-338.

Kogut, B. and U. Zander (1996), "What Firms Do?: Coordination, Identity, and Learning," Organization Science, 7, pp. 502-518. 
Kohn, A. (1993), Punished by Reward: The Trouble With Gold Stars, Incentive Plans, A's, Praise, and Other Bribes, Boston: Houghton Mifflin.

Koza, M. P. and A. Y. Lewin (1997), "The Co-evolution of Strategic Alliances," Organization Science, 9, pp. 255-264.

Krogh, G. von (1998), "Care in Knowledge Creation," California Management Review, 40, pp. 133-153.

Kruglanski, A. W. (1975), "The Endogenous-Exogenous Partition in Attribution Theory," Psychological Review, 82, pp. 387-406.

Lane, R. E. (1991), The Market Experience, Cambridge: Cambridge University Press.

Langlois, R. N. and N. J. Foss (1999), "Capabilities and Governance: The Rebirth of Production in the Theory of Economic Organization," Kyklos, 52, pp. 201-218.

Lawler, E. E. III (1990), Strategic Pay, San Francisco: Jossey-Bass.

Lazear, E. P. (1996), "Performance Pay and Productivity," NBER Working Paper 5672.

Leonard, D. and S. Sensiper (1998), "The Role of Tacit Knowledge in Group Innovation," California Management Review, 40, pp. 112-131.

Lepper, M. R. and D. Greene (eds.) (1978), The Hidden Costs of Reward: New Perspectives on the Psychology of Human Motivation, Hillsdale, NY: Erlbaum.

Liebeskind, J. P. (1996), "Knowledge, Strategy, and the Theory of the Firm," Strategic Management Journal, 17 (Winter Special Issue), pp. 93-107.

Likert, R. (1961), The New Patterns Of Management, New York: McGraw-Hill.

Loewenstein, G. (1999), "Because it is There: The Challenge of Mountaineering ... for Utility Theory," Kyklos, 52, pp. 315-343. 
Madhok, A. (1997), "Cost, Value and Foreign Market Entry Mode: The Transaction and the Firm," Strategic Management Journal, 18, pp. 39-61.

March, J. M. (1994), A Primer on Decision Making, New York: Free Press.

March, J. M. (1999), The Pursuit of Organizational Intelligence, Malden, Mass. and Oxford, UK: Blackwell.

March, J. G. and H. A. Simon (1958), Organizations, New York: Wiley.

McGregor, D. (1960), The Human Side of Enterprise, New York: McGraw-Hill.

Miles, R. E., C. C. Snow, J. A. Mathews, G. Miles and H. J. Coleman (1997), "Organizing in the knowledge age: Anticipating the cellular form," Academy of Management Executive, 11, pp. 7-24.

Milgrom, P. R. and J. Roberts (1992), Economics, Organization and Management, Englewood Cliffs, NJ: Prentice-Hall.

Montesquieu, C. L. (1749), De l'esprit des lois, Paris: Garnier.

Morrison, E. W. and S. L. Robinson (1997), "When Employees Feel Betrayed: A Model of How Psychological Contract Violation Develops," Academy of Management Review, 22, 1, pp. 226-256.

Nahapiet, J. and S. Ghoshal (1998), "Social Capital, Intellectual Capital and the Organizational Advantage," Academy of Management Review, 23, pp. 242-266.

Nelson, R. R. (1991), "Why do Firms Differ and How Does it Matter?," Strategic Management Journal, 12 (Special Issue), pp. 61-74.

Nonaka, I. and H. Takeuchi (1995), The Knowledge-Creating Company, New York and Oxford: Oxford University Press.

Nonaka, I. and N. Konno (1998), "The Concept of "Ba": Building a Foundation for Knowledge Creation," California Management Review, 40, pp. 40-54. 
Pettigrew, A. and R. Whipp (1993), Managing Change for Competitive Success, Oxford and Cambridge, Mass.: Blackwell.

Pfeffer, J. (1997), New Directions for Organization Theory, New York and Oxford: Oxford University Press.

Pittman, T. S. and J. F. Heller (1987), "Social Motivation," Annual Review of Psychology, 38, pp. 461-489.

Polanyi, M. (1966), The Tacit Dimension, London: Routledge and Kegan Paul.

Prahalad, C. K. and G. Hamel (1990), "The Core Competence of the Corporation," Harvard Business Review, 68 (May-June), pp. 79-91.

Prendergast, C. (1999), "The Provision of Incentives in Firms," Journal of Economic Literature, 37 (March), pp.7-63.

Raia, A. P. (1974), Managing by Objectives, Glenview, IL: Scott \& Foresman.

Richardson, J. (1996), "Vertical Integration and Rapid Response in Fashion Apparel," Organization Science, 7 (4), pp. 400-412.

Robinson, S. L., M. S. Kraatz and D. M. Rousseau (1994), "Changing Obligations and the Psychological Contract: A Longitudinal Study," Academy of Management Journal, 37, 1, pp. 137-152.

Rotter, J. B. (1966), "Generalized Expectancies for Internal Versus External Control of Reinforcement," Psychological Monographs, 80, 1, pp. 1-28.

Rousseau, D. M. (1995), Psychological Contracts in Organizations: Understanding Written and Unwritten Agreements, Thousand Oaks, London and New Dehli: Sage Publications.

Rousseau, D. M. and J. McLean Parks (1993), "The Contracts of Individuals and Organizations," Research in Organizational Behavior, 15, pp. 1-43.

Rumelt, R. P., D. Schendel and D. J. Teece (1991), "Strategic Management and Economics," Strategic Management Journal, 12, pp. 5-29. 
Rummel, A. and R. Feinberg (1988), "Cognitive Evaluation Theory: A MetaAnalytic Review of the Literature," Social Behavior and Personality, 16, pp. 147-164.

Sabel, C. F. (1993), "Constitutional Ordering in Historical Context," in: F. W. Scharpf (ed.), Games in Hierarchies and Networks, Frankfurt and New York: Campus: 65-123.

Schein, E. (1965), Organization Psychology, Englewood Cliffs, NJ: Prentice-Hall.

Schwartz, B. (1990), "The Creation and Destruction of Value," American Psychologist, 45, pp. 7-15.

Simon, H. A. (1951), "A Formal Theory of the Employment Relationship," Econometrica, 19, pp. 293-305.

Smith, A. (1776), An Inquiry into the Nature and Causes of the Wealth of Nations, Reprinted 1981, London: Deut and Sane Ltd.

Spender, J. C. (1996), "Making Knowledge the Basis of a Dynamic Theory of the Firm," Strategic Management Journal, 17 (Winter Special Issue), pp. 4562.

Staijkovic, A. D. and F. Luthans (1997), "A Meta-Analysis of the Effects of Organizational Behavior Modification on Task Performance, 1975-95," Academy of Management Journal, 40, pp. 1122-1149.

Staw, B. M. (1975), Intrinsic and Extrinsic Motivation, Morristown, NY: General Learning Press.

Stigler, G. J. and G. S. Becker (1977), "De Gustibus Non est Disputandum," American Economic Review, 67 (March), pp. 76-90.

Sydow, J. and A. Windeler (1998), "Organizing and Evaluating Interfirm Networks: A Structurationist Perspective on Network Processes and Effectiveness," Organization Science, 9, pp. 265-284. 
Tang, S. H. and V. C. Hall (1995), "The Overjustification Effect: A Meta-Analysis," Applied Cognitive Psychology, 9, pp. 365-404.

Teece, D. J. (1998), "Capturing Value from Knowledge Assets: The New Economy, Markets for Know-how, and Intangible Assets," California Management Review, 40, pp. 55-79.

Titmuss, R. M (1970), The Gift Relationship, London: Allen and Unwin.

Tyler, R. R. (1990), Why People Obey the Law, New Haven, CT: Yale University Press.

Upton, W. (1973), Altruism, Attribution and Intrinsic Motivation in the Recruitment of Blood Donors, Selected Readings on Donor Motivation and Recruitment, vol. III, ed. by American Red Cross.

Wellins, R. S., W. C. Byham and J. M. Wilson (1991), Empowered Teams: Creating Self-Directed Work Groups that Improve Quality, Productivity, and Participation, San Francisco: Jossey-Bass.

Wiersma, U. J. (1992), "The Effects of Extrinsic Rewards on Intrinsic Motivation: A Meta-Analysis," Journal of Occupational and Organizational Psychology, 65, pp. 101-114.

Williamson, O. E. (1975), Markets and Hierarchies: Analysis and Antitrust Implications: A Study in the Economics of Internal Organization, New York: Free Press.

Williamson, O. E. (1985), The Economic Institutions of Capitalism: Firms, Markets, Relational Contracting, New York: Free Press.

Williamson, O. E. (1991), "Comparative Economic Organization: The Analysis of Discrete Structural Alternatives," Administrative Science Quarterly, 36, pp. 269-296.

Williamson, O. E. (1996), "Economic Organization: the Case for Candor," Academy of Management Review, 21, pp. 48-57. 
Winter, S. G. (1995), "Four R's of Profitability: Rents, Resources, Routines and Replication," in: C. A. Montgomery (ed.), Resource-based and Evolutionary Theories of the Firm, Boston: Kluwer: 147-178.

Zander, U. and B. Kogut (1995), "Knowledge and the Speed of Transfer and Imitation of Organizational Capabilities: An Empirical Test," Organization Science, 6, pp. 76-92. 


\section{Endnotes}

1 Polanyi (1966, p. 4) explains the importance of tacit knowledge with the following example: "You can identify one face out of thousands, but it is nearly impossible to give an adequate description of this face to another person, so that she is able to identify the face."

2 The distinction between tacit and explicit knowledge should not be understood as a dichotomy but rather as a continuum (Zander and Kogut 1995).

3 For a comprehensive survey on the existing economic theory and empirical evidence regarding incentives in firms, in particular the principal agent approach, see Prendergast (1999).

4 For an extensive discussion of the distinction between extrinsic and intrinsic motivation, see e.g. Atkinson (1964); deCharms (1968); Deci (1975); Staw (1975).

5 Examples are intrinsic motivation in the form of trust (Arrow 1974), sentiments (Akerlof and Yellen 1986; Frank 1992), firm loyalty (Baker, Jensen and Murphy 1988), managerial incentives (Güth 1995), implicit contracts (Akerlof 1982).

6 See also Brennan and Buchanan (1985) for the case of the constitution.

7 Therefore, the economic theory of organization has been called the "science of suspicion" (Sabel 1993). 
8 For the same reason, extrinsically motivated warriors, in particular mercenaries or professional soldiers treated prisoners of war more humanely than ideologically or religously, i.e. intrinsically motivated, warriors did, see Frey (1999).

9 This problem has led to the recent success of the balanced scorecard concept, see Kaplan and Norton (1996).

10 Surveys are given in Lane (1991); Lepper and Greene (1978) and Pittman and Heller (1987). Kohn (1993) provides a popular application.

11 See, e.g., the experiments in Enzle and Anderson (1993).

12 This is also true in situations where coordination is effected by commands inside the firm, as envisaged by the authority-based view of the firm (e.g., Conner and Prahalad 1996; Williamson 1975). Commands can transfer explicit knowledge only.

13 The problems connected with transfer pricing are extensively discussed in Eccles (1985).

14 Empirical evidence for the car industry is given in Gaitanides (1997).

15 The latter case is treated in Conner and Prahalad (1996).

16 See Grant (1996a). He refers to Demsetz (1991) who, however, does not distinguish between tacit and explicit knowledge. But this distinction is crucial for our argument. 
17 For empirical evidence see Feldman (1996); Staijkovic and Luthans (1997).

18 While intrinsic motivation is crucial for cooperation within knowledge-based production teams, extrinsic motivation may have an influence on the decision whether to join a particular team. This refers to the distinction made by March and Simon (1958) between the motivation to participate versus the motivation to produce. To participate in a team depends often on extrinsic factors such as expected monetary rewards or reputation. In contrast, to contribute one's tacit knowledge within a team hinges on intrinsic motivation.

19 A possible supporting staff might contribute well-defined inputs such as basic clerical work, i.e., their relationship to the knowledge worker involves no tacit knowledge. In contrast to cell 1 , the fulfillment of their tasks can be laid out in explicit contracts. 